\title{
Influence of ripening index and water regime on the yield and quality of "Moroccan Picholine" virgin olive oil
}

\author{
Mohamed El Yamani*, El Hassan Sakar, Abdelali Boussakouran and Yahia Rharrabti \\ Laboratory of Natural Resources and Environment, Polydisciplinary Faculty of Taza, Sidi Mohamed Ben Abdellah University, \\ Taza, Morocco
}

Received 20 December 2019 - Accepted 15 March 2020

\begin{abstract}
The purpose of this work is to evidence the effects of ripening index and water regime on the quantity and quality indices of "Moroccan Picholine" virgin olive oil (VOO) produced in northern Morocco. Olive trees were subjected to full irrigation and rainfed conditions, and olive fruits were collected at different ripening times. Results showed that the extracted volume of VOO increased during ripening, and decreased when full irrigation was applied. In regard to VOO quality, the statistical analysis revealed the predominant effect of ripening index on the majority of the considered parameters, except total phenols content that was strongly influenced by water regime. At more advanced stages of maturity, lower values of peroxide value, K232, carotenoids, chlorophylls and total phenols were registered while more free fatty acids were accumulated. Moreover, full irrigation reduced total phenols and increased free fatty acids, even if a great amount of pigment content was scored. Correlation studies showed significant relationships between pigments content and oxidation indices (peroxide value and K232).
\end{abstract}

Keywords: irrigation / oil quality indices / oil extraction / olive maturation / VOO

\begin{abstract}
Résumé - Influence de l'indice de maturité et du régime hydrique sur le rendement et la qualité de I'huile d'olive vierge «Picholine marocaine». L'objectif de ce travail est de mettre en évidence les effets de l'indice de maturité et du régime hydrique sur le rendement oléique et les indices de qualité de l'huile d'olive vierge «Picholine marocaine» produite au nord du Maroc. Des arbres d'olivier ont été soumis à une irrigation complète et à des conditions pluviales (Bour), et les échantillons d'olives ont été récoltés à différents stades de maturité. Les résultats ont montré que la teneur extraite de l'huile d'olive augmentait avec la maturité des olives, tandis que l'application d'une irrigation complète la faisait diminuer. Quant à la qualité d'huile d'olive, l'analyse statistique a révélé l'effet prédominant de l'indice de maturité sur la majorité des paramètres étudiés, à l'exception de la teneur en phénols totaux qui était fortement influencée par le régime hydrique. En fait, à des stades de maturité plus avancés, des valeurs plus faibles de l'indice de peroxyde, de K232, de caroténoïdes, de chlorophylles et de phénols totaux ont été enregistrées, alors que les acides gras libres se sont davantage accumulés. En outre, l'irrigation complète a réduit la teneur en phénols totaux et a augmenté celle des acides gras libres, bien qu'une quantité importante de pigments ait été notée. Les études de corrélation ont établis des relations significatives entre la teneur en pigments et les indices d'oxydation (indice de peroxyde et K232).
\end{abstract}

Mots clés : irrigation / indices de qualité d'huile / extraction d'huile / maturité des olives / huile d'olive vierge

\section{Introduction}

Olive (Olea europaea L.) is the main crop fruit in the Mediterranean basin, and olive oil is a basic component of the diet in the region (Serra-Majem et al., 2003). Mediterranean countries are the main producers with $97 \%$ of the worldwide

\footnotetext{
*Correspondence: elyamani.med90@gmail.com
}

olive oil production estimated at 3159500 tons in the 2016 crop season. Morocco is the sixth world producer of olive oil after Spain, Italy, Greece, Turkey, and Tunisia (IOC, 2016). "Moroccan Picholine" is the most cultivated variety and accounts for more than $96 \%$ of cultivated olive trees nationwide (MAPMDREF, 2019).

World consumption of olive oil is still increasing, even in countries that have no history of olive growing, and it is 


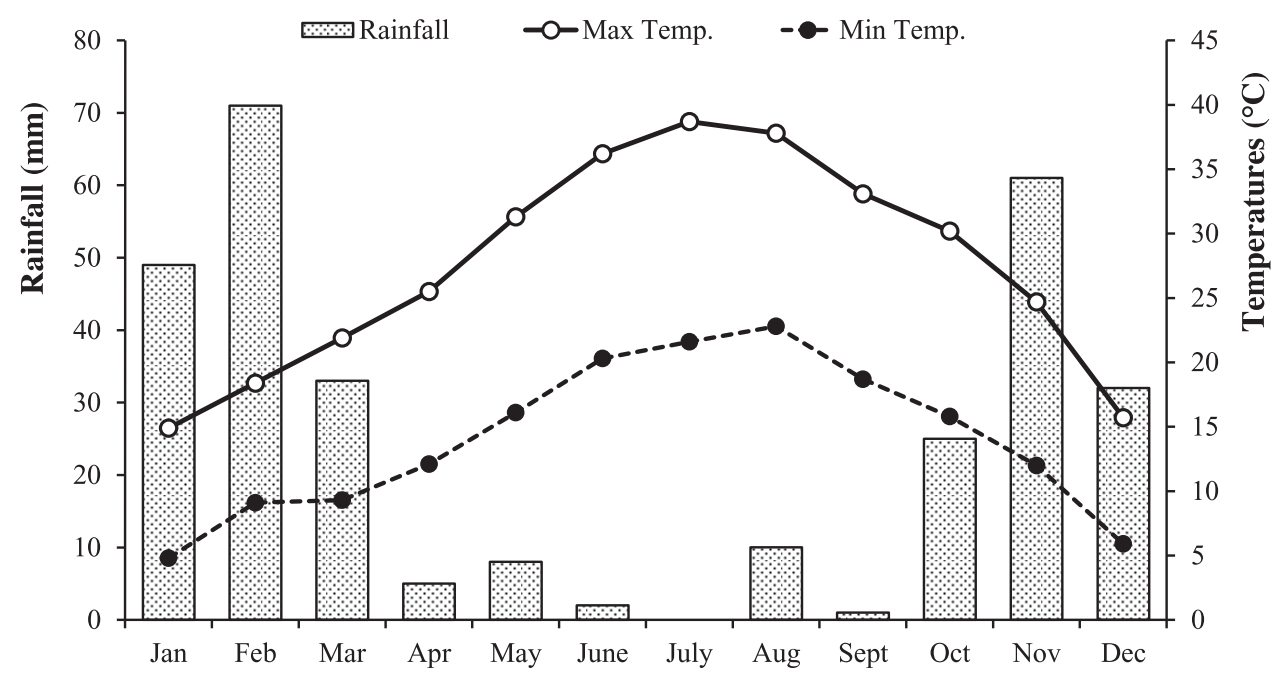

Fig. 1. Annual patterns of 2017 year for air temperatures and rainfall in Taza province (northern Morocco).

generally in parallel with production rate (Mili, 2006). The significant rise in demand and consumption of olive oil is due to its nutritional value and beneficial health properties including anti-oxidant, anti-atherogenic, anti-inflammatory, anti-tumor, anti-viral, anti-cancer and immune modulator activities (Covas, 2007; Fitó et al., 2007; Bendini et al., 2007; López-Miranda et al., 2010; Cárdeno et al., 2013).

The chemical characteristics and quality of virgin olive oil are influenced by several factors, including genotype, tree age, fruit ripening, productions area, pedoclimatic conditions, agronomic and irrigation practices and extraction process (Zamora et al., 2001; Rotondi et al., 2004; Abaza et al., 2005; Ben Temime et al., 2006; Baccouri et al., 2007; Gómez-Rico et al., 2007; Ouni et al., 2011; Jiménez et al., 2013; Yorulmaz et al., 2013; Gouvinhas et al., 2015).

VOO quality is strongly related to fruit maturation. An increase in polyunsaturated fatty acids associated with a loss in total phenols, pigments and oxidative stability, as the olives ripen, was reported in many studies (Gutiérrez et al., 2000, Morelló et al., 2004; Rotondi et al., 2004; Ayton et al., 2007). Ben Youssef et al. (2010) showed reductions in peroxide value, coefficient extinction at 232 and $270 \mathrm{~nm}$, chlorophylls, carotenoids and oleic acid contents during ripening. Similarly, Nsir et al. (2017) and Piscopo et al. (2018) observed a decrease tendency in qualitative parameters in VOO produced from later stage of olive ripening.

With respect to water regime, results from previous researches are conflicting. No impact of the tree water status on free acidity, peroxide value, K232 and K270 was documented (Servili et al., 2007; Tognetti et al., 2007; García et al., 2013; Rufat et al., 2018). However, Ismail et al. (1997) and Motilva et al. (1997) noticed higher free fatty acids, peroxide value, total phenols, and oxidative stability in oils extracted from irrigated trees compared to those extracted from water stressed trees. Contrariwise, total phenols, the most affected olive oil components, are significantly higher in VOO from stressed trees than from irrigated ones (Romero et al., 2002; Berenguer et al., 2006; Servili et al., 2007; Fernandes-Silva et al., 2013; García et al., 2017; Gucci et al., 2019).

The chemical and extracted olive oil yield is also under several impacts. Irrigation influence positively the oil content in olive fruits (Inglese et al., 1996; Patumi et al., 1999; Grattan et al., 2006; Tognetti et al., 2006; Gucci et al., 2007; Caruso et al., 2013). In contrast, Iniesta et al. (2009) observed the highest fruit oil content in deficit irrigated orchards. Moreover, moderately irrigated olive trees favored better oil extraction from the olive fresh weight (García et al., 2017). Oil content changes during fruit ripening process were also documented in several studies (Salvador et al., 2001; Zeleke et al., 2012). In fact, oil content accumulates in olive fruits as the ripening progresses (Motilva et al., 2000; Dag et al., 2011; Bakshi et al., 2018; Sönmez et al., 2018). In the same trend, Benito et al. (2013) and Mena et al. (2018) reported an increase in the industrial oil yield during olive maturation.

Therefore, the purposes of this study were to investigate the effect of olive ripening stage and water regime on the yield and quality of "Moroccan Picholine" VOO (Olea europaea L.) produced in northern Morocco.

\section{Materials and methods}

\subsection{Experimental design and environmental conditions}

The present investigation was carried out during the 2017 crop season, on the widely grown olive variety "Moroccan Picholine" in an experimental olive grove located at Taza province $\left(34^{\circ} 12^{\prime} 36^{\prime \prime} \mathrm{N}, 3^{\circ} 52^{\prime} 0^{\prime \prime} \mathrm{W}, 530 \mathrm{~m}\right.$ asl) in northern Morocco. The soil in the site is a Typic Xerofluvent, a weakly developed soil of alluvial contribution with a silty clay loam texture and parental material from middle and old quaternary. The climate is Mediterranean-type with mild and humid winters and dry and hot summers. Total annual rainfall and the average minimum and maximum temperatures during 2017 were $297 \mathrm{~mm}, 14.0^{\circ} \mathrm{C}$ and $27.4^{\circ} \mathrm{C}$, respectively. Annual reference evapotranspiration $\left(\mathrm{ET}_{0}\right)$ was $1817 \mathrm{~mm}$. Monthly data (precipitations and air temperatures) are displayed in Figure 1.

Thirty adult trees, spaced $6 \mathrm{~m}$ apart, were subjected to two water regimes: i) Fully irrigated with trees receiving $100 \%$ of water amount needs during irrigation period, and ii) and trees under rainfed condition that did not receive any irrigation. 
Each treatment consisted of 15 trees, distributed in three replicates laid out in a randomized block design.

The water requirements for the irrigated plot was estimated based on crop evapotranspiration (ETc) calculated using the Penman-Monteith method (Allen et al., 1998), and supplied through a drip irrigation system, with two on-line drippers $(4 \mathrm{~L} / \mathrm{h})$ per tree, each placed $0.75 \mathrm{~cm}$ from the tree-trunk base. The irrigation was applied once a week from June to the beginning of September, which coincides with high atmospheric demands for water vapour, and corresponds to fruit set (BBCH 69) and pit hardening stages (BBCH 71-79) and the period of the fastest oil synthesis (BBCH 80-81) (Gómez del Campo and García, 2013). Trees of the second plot were left unirrigated (rainfed conditions). During the irrigation period, the cumulative rainfall and $\mathrm{ET}_{0}$ were $13 \mathrm{~mm}$ and $883 \mathrm{~mm}$, respectively; while the average minimum and maximum temperatures were 21.3 and $37.0^{\circ} \mathrm{C}$, respectively.

Three olive samples ( $2 \mathrm{~kg}$ for each sample) were handpicked randomly from three olive trees representing each treatment at three ripening stages based on the degree of skin and pulp color. The sampling dates were as follows: 24 September (green skin color), 6 October (green skin color with reddish spots), 20 October (red to purple skin color), 15 November (purple to black skin color with white flesh color), and 27 December (black skin color with violet flesh color).

\subsection{Ripening index determination}

The ripeness index (RI), for olives collected at three maturation stages, was determined according to the method developed at the Agronomic Station of Jaén (Spain) (Uceda et al., 1998). It is based on a scoring system for each stage of colouring of the skin and flesh. The RI was obtained on 100 randomly olive fruits in each sample freshly picked, by applying the following formula:

$$
\begin{gathered}
\mathrm{RI}=\mathrm{A} 0+\mathrm{B} 1+\mathrm{C} 2+\mathrm{D} 3+\mathrm{E} 4 \\
+\mathrm{F} 5+\mathrm{G} 6+\mathrm{H} 7 \\
100,
\end{gathered}
$$

where A, B, C, D, E, F, G, and $\mathrm{H}$ are the number of fruits in each of the colour categories $0,1,2,3,4,5,6$, and 7 , respectively.

\subsection{Oil extraction}

The healthy olive fruits hand-picked at different ripening stages from trees under the two water regimes were immediately transported to the laboratory. Olive oil extraction was performed at the Laboratory of Natural Resources and Environment of the Polydisciplinary Faculty of Taza (Morocco) using a lab-scale instrument reproducing industrial conditions for oil extraction; olives were crushed with a hammer crusher, the resulting paste was slowly mixed at room temperatures for $30 \mathrm{~min}$, and the oil was separated by centrifugation ( $3000 \mathrm{rpm}$ over $5 \mathrm{~min}$ ) without addition of warm water. The obtained oil was filtered, transferred into amber glass bottles without headspace, and stored in the dark at $4{ }^{\circ} \mathrm{C}$ until analyses.

The industrial oil yield (extracted oil), given in percentage of fresh olive paste weight (W) and considering the olive oil density (D) at ambient temperature of $0.915 \mathrm{~g} \cdot \mathrm{mL}^{-1}$, was determined using the formula (Mena et al., 2018):

$$
\text { Extracted oil }(\%)=\frac{\mathrm{V} \times \mathrm{D}}{\mathrm{W}} \times 100,
$$

Where $\mathrm{V}$ is the volume of olive oil obtained $(\mathrm{mL})$.

\subsection{Olive oil analysis}

\subsubsection{Quality indices}

Determination of free fatty acids, peroxide value, and specific wavelength absorbance at $232 \mathrm{~nm}$ and $270 \mathrm{~nm}$ (K232 and K270) were carried out, following the analytical methods described in Regulations EEC/2568/91 and later modifications of the Commission of the European Union (EEC, 1991, 2003).

Free fatty acids, expressed as \% of oleic acid, was determined by titration of a mixture of oil sample $(20 \mathrm{~g})$ dissolved in ethanol $(50 \mathrm{~mL})$ with ethanolic solution of potassium hydroxide $(0.1 \mathrm{~N})$. Phenolphthalein was used as indicator.

Peroxide value, expressed in milliequivalents of active oxygen per kilogram of oil (meq $\mathrm{O}_{2} / \mathrm{kg}$ ), was measured in the following procedure: olive oil sample $(5 \mathrm{~g})$ was dissolved in a solution of chloroform-acetic acid $(30 \mathrm{~mL})$ then the mixture was left to react with a solution of potassium iodide in darkness. The liberated iodine by the peroxides was titrated with standardized sodium thiosulphate solution using starch as indicator.

K232 and K270 were calculated from absorption at 232 and $270 \mathrm{~nm}$, respectively, with a UV spectrophotometer (SPECUVIS1; UV-Visible), using a $1 \%$ solution of olive oil in cyclohexane $(1 \mathrm{~g} / 100 \mathrm{~mL})$ and a path length of $1 \mathrm{~cm}$.

\subsubsection{Pigments}

The pigment contents $(\mathrm{mg} / \mathrm{kg}$ of oil) were determined colorimetrically using SPECUVIS1 spectrophotometer; UVVisible, following the method described by MinguezMosquera et al. (1991). A sample of $7.5 \mathrm{~g}$ oil was dissolved in $25 \mathrm{~mL}$ of cyclohexane. The absorbance of this solution was read at 670 and $470 \mathrm{~nm}$ for chlorophylls and for carotenoids, respectively. The values of the specific extinction coefficients used were 613 for pheophytin as major component in the chlorophyll fraction, and 2000 for lutein as major component in the carotenoid fraction. Thusly, pigment contents were calculated using the following equations:

$$
\begin{aligned}
& \text { Chrolophylls }\left(\frac{\mathrm{mg}}{\mathrm{kg}}\right)=\frac{\mathrm{A}_{670} \times 10^{6}}{613 \times 100 \times \mathrm{L}}, \\
& \text { Carotenoids }\left(\frac{\mathrm{mg}}{\mathrm{kg}}\right)=\frac{\mathrm{A}_{470 \times 10^{6}} \times 100 \times \mathrm{L}}{2000 \times 100}
\end{aligned}
$$

Where $\mathrm{A}$ is the absorbance and $\mathrm{L}$ is the spectrophotometer cell thickness $(1 \mathrm{~cm})$.

\subsubsection{Total phenols}

Total phenols were isolated according to the method described by Zunin et al. (1995). Olive oil samples (10 g) 
dissolved in n-hexane $(10 \mathrm{~mL})$ were extracted three times with aqueous methanol $(60 / 40, \mathrm{v} / \mathrm{v}, 10 \mathrm{~mL})$. The concentration of total phenols was determined spectrophotometrically (SPECUVIS1; UV-Visible) following the method of Folin and Ciocalteu (1927). Folin-Ciocalteau reagent was added to a suitable dilution of the extract, and the absorbance was measured at $750 \mathrm{~nm}$ using as standard the caffeic acid (SigmaAldrich, St. Louis, MO, USA). Values for total phenols content are given as $\mathrm{mg}$ caffeic acid/kg oil.

\subsection{Statistical analyses}

All determinations were performed in three replicates. The two-way analysis of variance (ANOVA) was carried out over ripening index and water regimes. Least significant difference (LSD) values were calculated at the 5\% probability level. The relationships between the studied parameters were established on the mean data of all the replicates. The STATGRAPHICS Centurion XVII package (Stat point Technologies, Inc., Virginia, USA) was used for all the calculations.

\section{Results}

\subsection{Extracted oil}

Mean values of the extracted olive oil from the olive fresh weight (\%) at each ripening index and water regime are shown in Figure 2. The VOO extracted showed a significant variation among the considered maturation stages of olive fruits; it increased consistently with RI and ranged from $7.43 \%$ at the early stage to $16.10 \%$ at the latest one, with an average value of $10.89 \%$. In relation to water regime, higher extracted oil was scored in olive fruits from trees under rainfed conditions $(11.63 \%)$, in comparison to those from fully irrigated regime $(10.15 \%)$. In addition, evolution of extracted oil amount with ripening index was slightly greater in rainfed regime than in the fully irrigated one.

\section{Olive oil quality}

\subsection{Data variability}

The combined analyses of variance (ANOVA) of "Moroccan Picholine" VOO produced from olive fruits harvested at different ripening index in trees grown under fully irrigated and rainfed regimes are summarized in Table 1. The ANOVA test showed that peroxide value, pigment (carotenoids and chlorophylls) contents and K232 were predominantly influenced by the ripening index that assigned more than $78 \%$ of the observed variance. Total phenols were mainly under the impact water regime $(93 \%)$. Free fatty acids were highly affected by ripening index $(64 \%)$ and in lesser extent by water regime $(29 \%)$. The interaction "ripening index $\times$ water regime" had minor influence on all analyzed parameters.

\subsection{Effect of ripening index}

The mean values of the parameters considered in this work with regard to ripening index are shown in Table 2 . Free fatty
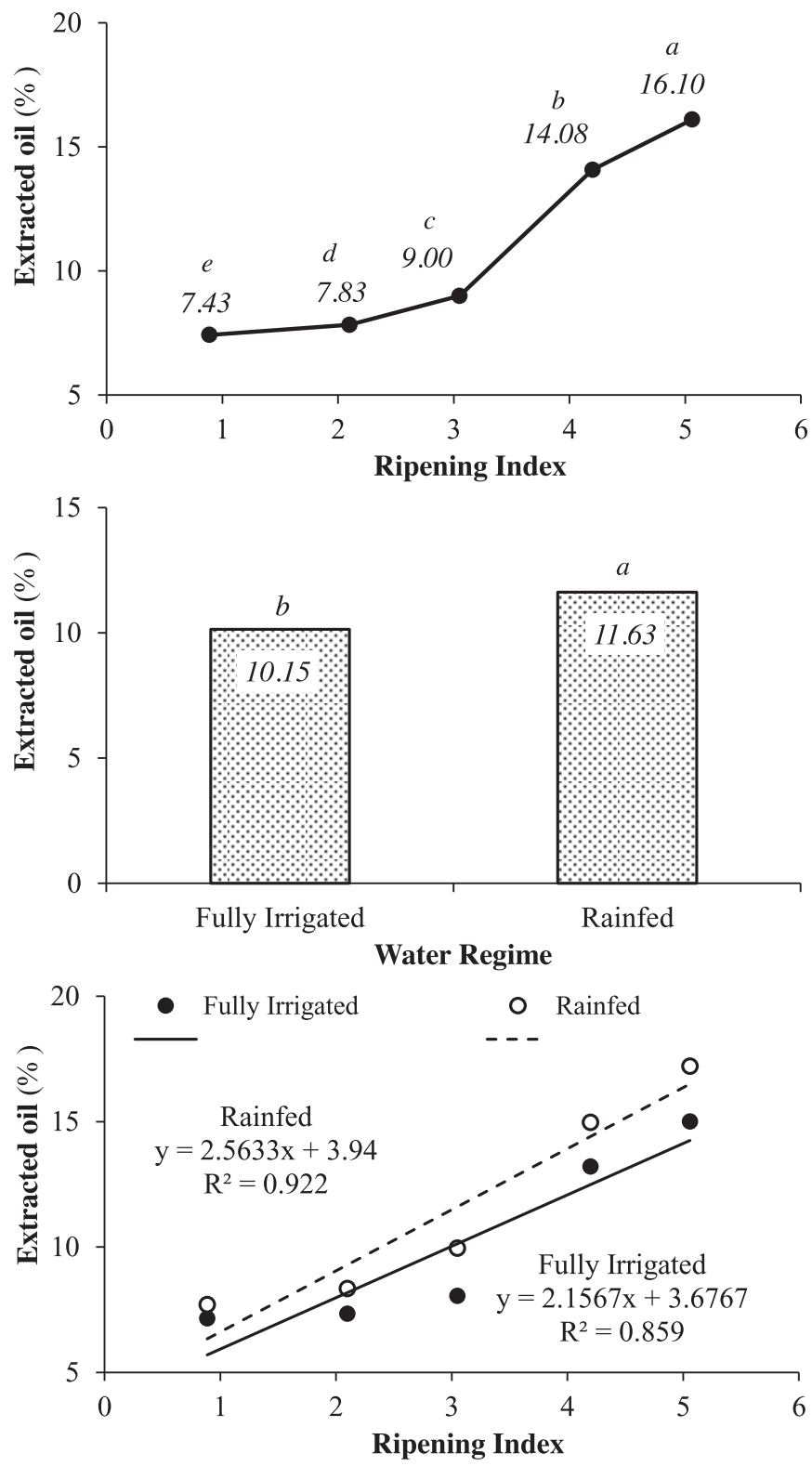

Fig. 2. Evolution of extracted "Moroccan Picholine" virgin olive oils from olive fruits harvested at three successive ripening index $(\mathrm{RI}=0.89 ; 3.05$ and 5.06) from trees grown in Taza province under two water regimes (Fully irrigated and rainfed) during the 2017 crop season.

acids increased significantly from $0.28 \%$ at early repining stage $(R I=0.89)$ to $0.35 \%$ at later stage $(R I=5.05)$. In contrast, a significant decrease was observed for peroxide value and K232 when RI increased. Similarly, pigment contents showed a reduction tendency towards the progressing of olive maturation. The minimum levels are reached at black pigmentation $(\mathrm{RI}=5.06)$, and were of 0.92 and $1.45 \mathrm{mg} / \mathrm{kg}$ for carotenoids and chlorophylls, respectively. Total phenols content also varied markedly with RI; the lowest value $(442.85 \mathrm{mg} / \mathrm{kg}$ caffeic) was scored in oils produced from fruit olives with the RI equal to 5.06 . 
Table 1. Mean squares of the combined analyses of variance of "Moroccan Picholine" virgin olive oil produced from olive fruits harvested at three successive ripening index $(\mathrm{RI}=0.89 ; 3.05$ and 5.06) from trees grown in Taza province under two water regimes (Fully irrigated and rainfed) during 2017 the crop season.

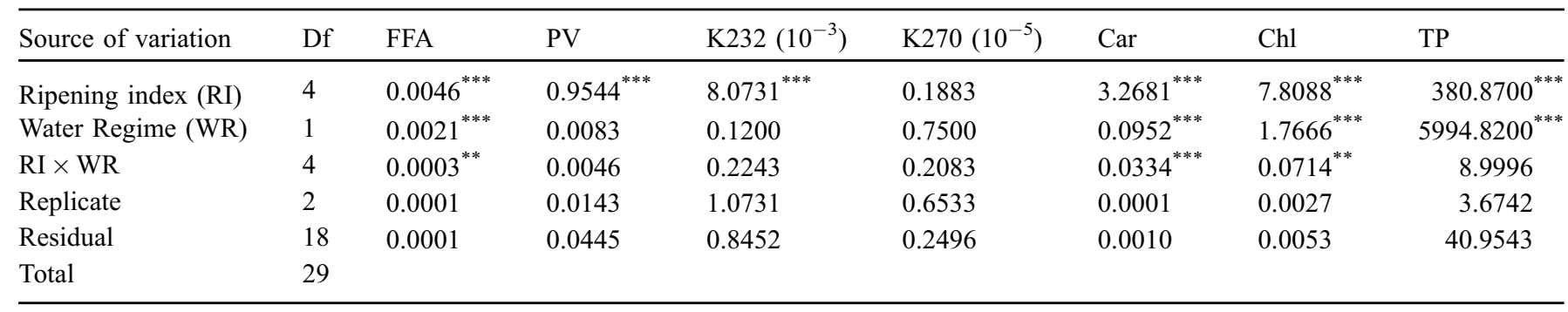

FFA: free fatty acids, PV: peroxide value, K232 and K270: extinction coefficients at $232 \mathrm{~nm}$ and $270 \mathrm{~nm}$, Chl: chlorophylls, Car: carotenoids, TP: total phenols.

${ }^{*}$ Significant at 0.05 probability level; ${ }^{* *}$ Significant at 0.01 probability level; ${ }^{* * *}$ Significant at 0.001 probability level.

Table 2. Mean values of analytical characteristics of "Moroccan Picholine" virgin olive oil produced from olive fruits harvested at three successive ripening index $(\mathrm{RI}=0.89 ; 3.05$ and 5.06) from trees grown in Taza province under two water regimes (Fully irrigated and rainfed) during the 2017 crop season.

\begin{tabular}{|c|c|c|c|c|c|c|c|}
\hline & FFA $(\%$ OA $)$ & $\mathrm{PV}\left(\right.$ meq $\mathrm{O}_{2} / \mathrm{kg}$ ) & K232 & $\mathrm{K} 270$ & Car $(\mathrm{mg} / \mathrm{kg})$ & $\mathrm{Chl}(\mathrm{mg} / \mathrm{kg})$ & TP $(\mathrm{mg} / \mathrm{kg}$ caffeic) \\
\hline \multicolumn{8}{|l|}{ Ripening index } \\
\hline 0.89 & $0.28 \mathrm{~d}$ & $6.94 \mathrm{a}$ & $1.505 \mathrm{a}$ & $0.176 \mathrm{a}$ & $2.67 \mathrm{a}$ & $4.25 \mathrm{a}$ & $458.72 \mathrm{ab}$ \\
\hline 3.05 & $0.30 \mathrm{c}$ & $6.28 \mathrm{c}$ & $1.494 \mathrm{ab}$ & $0.175 \mathrm{a}$ & $1.84 \mathrm{c}$ & $3.28 \mathrm{c}$ & $462.85 \mathrm{a}$ \\
\hline 4.20 & $0.33 \mathrm{~b}$ & $6.16 \mathrm{~cd}$ & $1.464 \mathrm{~b}$ & $0.175 \mathrm{a}$ & $1.19 \mathrm{~d}$ & $2.29 \mathrm{~d}$ & $452.82 \mathrm{~b}$ \\
\hline Fully irrigated & $0.32 \mathrm{a}$ & $6.42 \mathrm{a}$ & $1.477 \mathrm{a}$ & $0.176 \mathrm{a}$ & $1.85 \mathrm{a}$ & $3.25 \mathrm{a}$ & $441.36 \mathrm{~b}$ \\
\hline Rainfed & $0.30 \mathrm{~b}$ & $6.39 \mathrm{a}$ & $1.473 \mathrm{a}$ & $0.175 \mathrm{a}$ & $1.73 \mathrm{~b}$ & $2.77 \mathrm{~b}$ & $469.63 \mathrm{a}$ \\
\hline
\end{tabular}

FFA: free fatty acids, PV: peroxide value, K232 and K270: extinction coefficients at $232 \mathrm{~nm}$ and $270 \mathrm{~nm}$, Chl: chlorophylls, Car: carotenoids, TP: total phenols. Means for each character followed by the same letter are not significantly different according to LSD test at $P<0.05$.

\subsection{Effect of water regime}

Concerning water regimes, statistical analyses evidenced some significant differences in tested oils (Tab. 2). The highest values for free fatty acids, carotenoids and chlorophylls $(0.32 \%, \quad 1.84 \mathrm{mg} / \mathrm{kg}$ and $3.26 \mathrm{mg} / \mathrm{kg}$, respectively) were measured in olive oils obtained from fully irrigated trees. In contrast, the rainfed conditions favored the production of total phenols ( $469.63 \mathrm{mg} / \mathrm{kg}$ caffeic) compared to the full irrigation $(441.36 \mathrm{mg} / \mathrm{kg}$ caffeic). No significant differences were revealed for peroxide value, K232 and K270 between the two water regimes.

\subsection{Relationships among parameters and factors}

Changes of the analytical parameters regarding both ripening index and water regime were plotted in Figure 3. An increase in free fatty acids was observed during maturation, which was more promoted by irrigation. In contrast, a significant decrease was detected during olive fruit ripening in peroxide value, K232 and K270 that appeared unaffected by the water regime. A similar behavior was shown for pigments with a slight effect of water regime. For total phenols, the same response to ripening index was observed under the two regimes; they decreased progressively as maturation progressed, however, oils produced from fully irrigated trees had lower contents that rainfed ones.

Results of the correlation study between the considered parameters of olive oils obtained from fruit olives at different ripening index from fully irrigated trees and those under rainfed conditions are presented in Table 3 . The most significant relationships were highlighted between pigment content and oxidation indices. Chlorophylls were strongly and positively associated with carotenoids $\left(r=0.971^{* * *}\right)$, K232 $\left(r=0.936^{* * *}\right)$ and peroxide value $\left(r=0.927^{* * *}\right)$. Carotenoids were highly correlated to peroxide value $\left(r=0.965^{* * *}\right)$ and $\mathrm{K} 232\left(r=0.891^{* *}\right)$. A significant association was also shown between Peroxide value and K232 $(r=0.822 * *)$. The other correlations were not significant and of minor importance.

\section{Discussion}

The analytical parameters examined in this study confirmed the effects of olive fruits ripeness and water regime on the industrial yield of extracted VOO and its quality. In fact, significant increase in extracted oil yield was observed during 

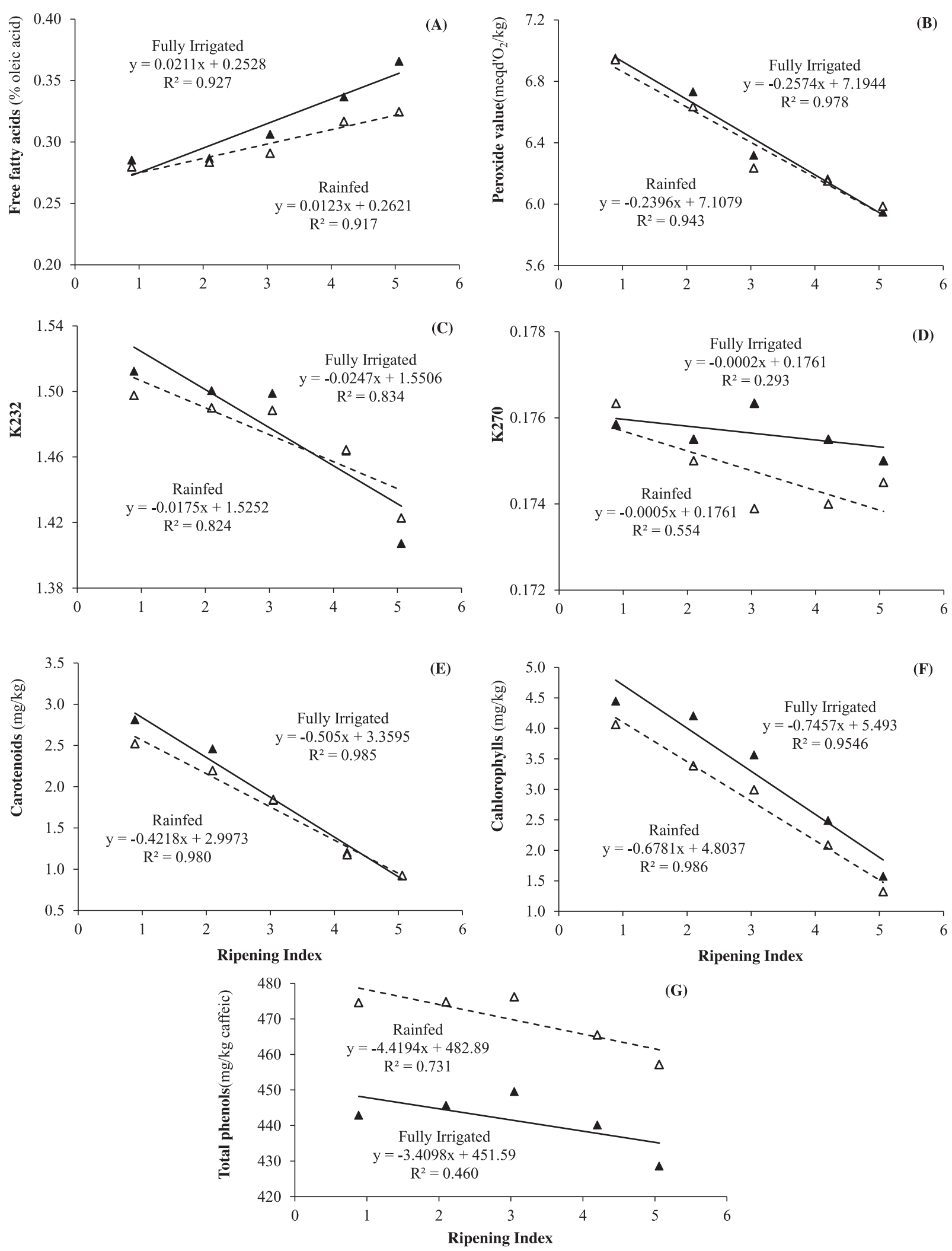

$\Delta$ Fully Irrigated

$\Delta$ Rainfed

Fig. 3. Evolution of free fatty acids (A), peroxide value (B), K232 (C), K270 (D), carotenoids (E), chlorophylls (F) and total phenols (G) in "Moroccan Picholine" virgin olive oil produced from olive fruits harvested at three successive ripening index $(\mathrm{RI}=0.89 ; 3.05$ and 5.06$)$ from trees grown in Taza province under two water regimes (Fully irrigated and rainfed) during the 2017 crop season. 
Table 3. Correlations between analytical characteristics for data from "Moroccan Picholine" virgin olive oil produced from olive fruits harvested at three successive ripening index $(\mathrm{RI}=0.89 ; 3.05$ and 5.06) from trees grown in Taza province under two water regimes (Fully irrigated and rainfed) during the 2017 crop season.

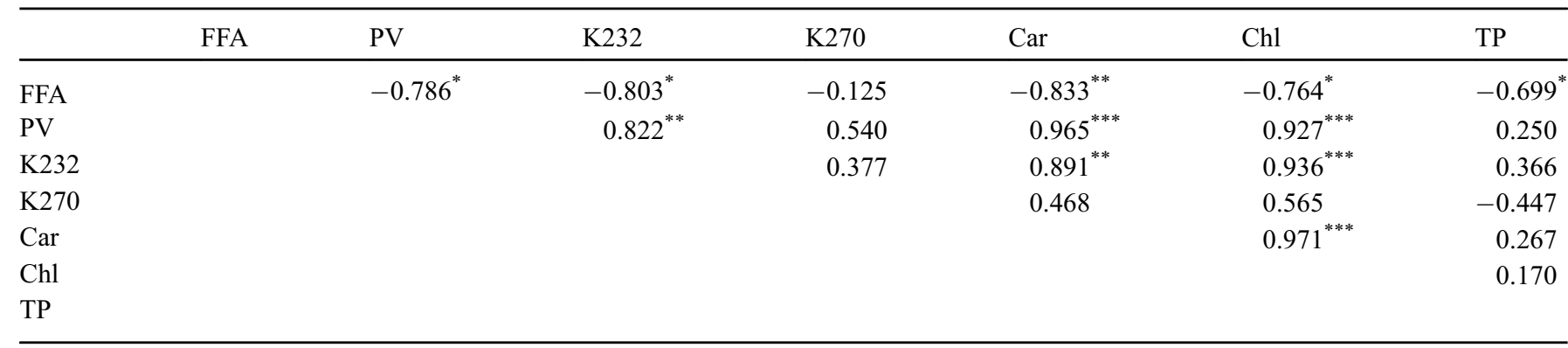

FFA: free fatty acids, PV: peroxide value, K232 and K270: extinction coefficients at $232 \mathrm{~nm}$ and $270 \mathrm{~nm}$, Chl: chlorophylls, Car: carotenoids, TP: total phenols.

${ }^{*}$ Significant at 0.05 probability level; ${ }^{* *}$ Significant at 0.01 probability level; ${ }^{* * *}$ Significant at 0.001 probability level.

ripening progress of olive fruits. Our results are consistent with previous studies. Mena et al. (2018) reported an increase from $12.14 \%$ to $15.48 \%$ of industrial oil yield produced from "Castellana" variety grown in Spain, during olive ripening, and explained this change by the loss of moisture of the olives as they ripened. The oil accumulation in olive fruits as the maturity progressed was also observed for several olive varieties such as "Leccino", "Messinese", "Picholina", "Etnea", "Itrana", "Coratina" and "Zaituna" (Zeleke et al., 2012, Zeleke and Ayton, 2014). Bakshi et al. (2018) attributed the rise in oil content during olive fruits growth to the biosynthesis of triglycerides until the fruit reached full maturity. In addition, Sanchez (1994) reported that oil accumulation in olives takes place before the start of the ripening process, when the fruit is green and photosynthetically competent, while the triacylglycerols formation reached a plateau when the color of the fruit turn from green to purple and then black.

Effect of water regime on extracted oil content was also revealed in the present work, which was in harmony with previous studies indicating that irrigation caused a decrease of mechanically extractable oil (Grattan et al., 2006; Morales-Sillero et al., 2011). The highest amount of oil physically extracted in relation to the fruit fresh weight was scored in the less-irrigated treatments (Iniesta et al., 2009; Ramos and Santos, 2010; García et al., 2017). Zeleke and Ayton (2014) noticed that the irrigation treatment significantly influenced the extractable olive oil that was higher in nonirrigated treatment compared to the fully and partially irrigated ones. The same authors announced that the mechanical extraction efficiency decreased with the fruit water content, since the irrigation treatment was not contrasting enough to affect the oil accumulation in olives. The greater oil yield (expressed as fresh weight of fruit) in stressed olives could be the result of higher water content in olives from the irrigated trees, which may affect negatively oil extraction (Motilva et al., 2000).

Concerning the VOO quality indices, the free fatty acids were influenced mainly by ripening index but also water regime. It increased significantly as fruit ripening progressed, which was in agreement with the results published previously (Gutiérrez et al., 1999, Salvador et al., 2001; Rotondi et al.,
2004; Yousfi et al., 2006; Dag et al., 2011; Bakshi et al., 2018). The high level of free fatty acids in VOO from olives at advanced maturation stage was attributed to an increase in enzymatic activity, especially by lipolitic enzymes, and to higher sensitivity to pathogenic infections (Martinéz-Suárez, 1973; Salvador et al., 2001). Between water regimes, the highest score of free fatty acids was observed in VOO from fully irrigated trees. Chehab et al. (2013) have also observed a tendency of increasing free fatty acids of virgin olive oil with increased irrigation levels. In addition, minor effects of water irrigation on free fatty acids were indicated in several studies (Servili et al., 2007; Allalout et al., 2009; Dabbou et al., 2011; 2015). However, no statistical differences between water regimes were reported in other investigations (Tovar et al., 2001; Caruso et al., 2014; Rufat et al., 2018). The high sensitivity to fly attack of olive fruits with higher water content from fully irrigated compared to rainfed trees could explain the differences detected in our study, as reported by Gómez-Rico et al. (2009) and Chehab et al. (2013).

The peroxide value was totally under the impact of ripening index. The lower values were obtained at the latest stage of olives maturity. The reduction in peroxide value during maturation process is well documented (Salvador et al., 2001; Baccouri et al., 2008; Ben Youssef et al., 2010; Dag et al., 2011). The behavior observed for the peroxide value was a consequence of a decrease in the lipoxygenase activity (Gutiérrez et al., 1999). The results obtained for K232 that is related to the primary oxidation of oil, were relatively similar to those for the peroxide value and are in conformity with other studies (Gómez-Rico et al., 2007; Baccouri et al., 2008). K270 is an indicator of the secondary oxidation products (aldehyds and ketones) in olives and was slightly affected by both the ripening index and water regime, but no statistical differences were detected. The effect of water regime on oil oxidation indices (peroxide value, K232 and K270) was of negligible magnitude, in contrast to the results of other authors who mentioned a significant effect of irrigation level on these indices (Gómez-Rico et al., 2007; Dabbou et al., 2015; García et al., 2017).

The changes in pigments of extracted VOO were controlled by ripening index. In fact, losses of both chlorophylls and carotenoids were observed as the olive fruits 
ripened. These findings match those already found by other authors (Gutiérrez et al., 1999; Beltrán et al., 2005; Ben Youssef et al., 2010; Bakshi et al., 2018; Piscopo et al., 2018). The progressive reduction of pigments with olive maturation is due firstly to decrease in the photosynthetic activity (Salvador et al., 2001) and also to the formation of other colored compounds, such as anthocyanins (Roca and MinguezMosquera, 2001). Significant differences were found for both chlorophylls and carotenoids between rainfed and fully irrigated trees. The highest contents were associated with the greatest level of irrigation, which was in agreement with the finding by Motilva et al. (2000) and Baccouri et al. (2008).

Total phenols were influenced by both the water regime and the ripening index, decreasing in fully irrigated treatment and as olives ripened. The changes in these substances regarding the mentioned factors confirmed the results obtained by Motilva et al. (2000) and Rufat et al. (2018). In the same way, it was indicated that higher levels of irrigation reduced the total phenols content in olive oils (Salas et al., 1997; Tovar et al., 2001; Romero et al., 2004; Gómez-Rico et al., 2007; Servili et al., 2007; Dag et al., 2008); while the highest concentrations were recorded at deficit-irrigated, and severely stressed trees or those grown under rainfed conditions (Motilva et al., 2000; Caruso et al., 2014; Gucci et al., 2019). Moreover, differences in total phenols amounts were related to many environmental conditions, especially the amount of water applied (Berenguer et al., 2006; Chehab et al., 2013; Marra et al., 2016; Sastre et al., 2016). In fact, it is known that the plant water status implied changes in the activity of Lphenylalanine ammonia lyase (PAL); the main enzyme responsible for phenolic compounds synthesis in drupes; its activity is reduced as the amount of water applied increased (Patumi et al., 1999; Tovar et al., 2002; Morelló et al., 2005). In relation to olive maturation, a reducing tendency of total phenols was observed during ripening, declining to the lower levels at RI of 5.06, in accordance with the findings reported by Vázquez-Roncero et al. (1971), Serman et al. (2011) and Piscopo et al. (2018). Similarly, a clear negative correlation was obtained between total phenols and RI (Rotondi et al., 2004; Dag et al., 2011). The total phenols content increased gradually until reaching a maximum at RI between 2 and 4 , after which it decreased (Salvador et al., 2001, Baccouri et al., 2008, Ben Youssef et al., 2010).

The correlation matrix from mean data presented in our work revealed a close positive relationship between pigments content (chlorophylls and carotenoids) and indicators of oil oxidation (peroxide value, K232 and K270). However, other authors reported a negative correlation and confirmed the antioxidant potential of carotenoids and chlorophylls (Velasco and Dobarganes, 2002; Szydłowska-Czerniak et al., 2011; El Yamani et al., 2019). The chlorophylls and their derivatives in presence of light promote the first phases of the autoxidation process (Cichelli and Pertesana, 2004; Ben Tekaya and Hassouna, 2007). The positive correlation between pigments content (especially carotenoids) and oxidation indicators could be due to their similar response to ripening index and water regime. A negative but not significant correlation was observed between total phenols and oxidation indicators, in agreement with numerous authors (Sifi et al., 2001; Torres and Maestri, 2006; El Yamani et al., 2019) who indicated the role of phenolic compounds in resisting to oxidation.

\section{Conclusions}

This work reports the changes in the extraction yield and different quality parameters of VOO from "Moroccan Picholine" in relation to olive fruit ripening and water regime. Our findings could be useful and of great importance to the olive oil industry for providing the optimal VOO quality with the high industrial oil yield. The optimum harvest period was clearly inconsistent with either early or advanced ripening stages. In fact, it is recommended that the harvesting should be carried before reaching advanced maturity of olive fruits, in order to get maximum oil yield while keeping its good quality. With regard to water regime, the best scores either for extraction yield or quality of olive oil were found for rainfed conditions. However, the influence of deficit irrigation levels needs further investigations.

Acknowledgements. Authors are thankful to the technical staff of the experimental olive grove. This work was supported by internal funding from Sidi Mohamed Ben Adellah University (Morocco).

Conflicts of interest. The authors declare no conflict of interest.

\section{References}

Abaza L, Taamalli W, Ben Temime S, Daoud D, Gutiérrez F, Zarrouk M. 2005. Natural antioxidant composition as correlated to stability of some Tunisian virgin olive oils. Riv Ital Sostanze $\mathrm{Gr}$ 132: $12-18$.

Allalout A, Krichène D, Methenni K, et al. 2009. Characterization of virgin olive oil from super intensive Spanish and Greek varieties grown in northern Tunisia. Sci Hortic 120: 77-83.

Allen RG, Pereira LS, Raes D, Smith M. 1998. Crop evapotranspiration-Guidelines for computing crop water requirements-FAO irrigation and drainage, $56 \mathrm{p}$. Rome: Food and Agriculture Organization of the United Nations 300: D05109.

Ayton J, Mailer RJ, Haigh A, Tronson D, Conlan D. 2007. Quality and oxidative stability of Australian olive oil according to harvest date and irrigation. J Food Lipids 14: 138-156.

Baccouri B, Temime SB, Taamalli W, Daoud D, M'Sallem MONJI, Zarrouk M. 2007. Analytical characteristics of virgin olive oils from two new varieties obtained by controlled crossing on Meski variety. J Food Lipids 14: 19-34.

Baccouri O, Guerfel M, Baccouri B, et al. 2008. Chemical composition and oxidative stability of Tunisian monovarietal virgin olive oils with regard to fruit ripening. Food Chem 109: 743-754.

Bakshi M, Guleria S, Jamwal S, Gupta M. 2018. Effect of harvesting time on yield, quality and fatty acid profile of olive oil produced in foothills of Himalayas. J Pharmacogn Phytochem 7: 3464-3469.

Beltrán G, Aguilera MP, Del Rio C, Sanchez S, Martinez L. 2005. Influence of fruit ripening process on the natural antioxidant content of Hojiblanca virgin olive oils. Food Chem 89: 207-215.

Ben Tekaya I, Hassouna M. 2007. Effets des chlorophylles, du bêtacarotène, de l'alphatocophérol, du tyrosol et de leurs interactions sur la stabilité oxydative de l'huile d'olive tunisienne. OCL 14: 60-67.

Ben Temime S, Taamalli W, Bacccouri B, Abaza L, Daoud D, Zarrouk M. 2006. Changes in olive oil quality of Chétoui variety according to origin of plantation. J Food Lipids 13: 88-99. 
Ben Youssef N, Zarrouk W, Carrasco-Pancorbo A, et al. 2010. Effect of olive ripeness on chemical properties and phenolic composition of chétoui virgin olive oil. J Sci Food Agric 90: 199-204.

Bendini A, Cerretani L, Carrasco-Pancorbo A, et al. 2007. Phenolic molecules in virgin olive oils: a survey of their sensory properties, health effects, antioxidant activity and analytical methods. An overview of the last decade Alessandra. Molecules 12: 16791719.

Benito M, Lasa JM, Gracia P, et al. 2013. Olive oil quality and ripening in super-high-density Arbequina orchard. J Sci Food Agric 93: 2207-2220.

Berenguer MJ, Vossen PM, Grattan SR, Connell JH, Polito VS. 2006. Tree irrigation levels for optimum chemical and sensory properties of olive oil. HortScience 41: 427-432.

Cárdeno A, Sánchez-Hidalgo M, Alarcón-De-La-Lastra C. 2013. An up-date of olive oil phenols in inflammation and cancer: molecular mechanisms and clinical implications. Curr Med Chem 20: 4758-4776.

Caruso G, Rapoport HF, Gucci R. 2013. Long-term evaluation of yield components of young olive trees during the onset of fruit production under different irrigation regimes. Irrig Sci 31: 37-47.

Caruso G, Gucci R, Urbani S, et al. 2014. Effect of different irrigation volumes during fruit development on quality of virgin olive oil of cv. Frantoio. Agric Water Manag 134: 94-103.

Chehab H, Issaoui M, Flamini G, et al. 2013. Oil quality and aroma composition of Chemlali olive trees (Olea europaea L.) under three irrigation regimes. Afr J Agric Res 8: 6291-6299.

Cichelli A, Pertesana GP. 2004. High-performance liquid chromatographic analysis of chlorophylls, pheophytins and carotenoids in virgin olive oils: chemometric approach to variety classification. J Chromatogr A 1046: 141-146.

Covas MI. 2007. Olive oil and the cardiovascular system. Pharmacol Res 55: 175-186.

Dabbou S, Dabbou S, Chehab H, et al. 2011. Chemical composition of virgin olive oils from Koroneiki cultivar grown in Tunisia with regard to fruit ripening and irrigation regimes. Int J Food Sci Technol 46: 577-585.

Dabbou S, Dabbou S, Chehab H, Taticchi A, Servili M, Hammami M. 2015. Content of fatty acids and phenolics in Coratina olive oil from Tunisia: Influence of irrigation and ripening. Chem Biodivers 12: 397-406.

Dag A, Ben-Gal A, Yermiyahu U, Basheer L, Nir Y, Kerem Z. 2008. The effect of irrigation level and harvest mechanization on virgin olive oil quality in a traditional rain-fed "Souri" olive orchard converted to irrigation. J Sci Food Agric 88: 1524-1528.

Dag A, Kerem Z, Yogev N, Zipori I, Lavee S, Ben-David E. 2011. Influence of time of harvest and maturity index on olive oil yield and quality. Sci Hortic 127: 358-366.

EEC. 1991. Characteristics of olive and olive pomace oils and their analytical methods. Regulation EEC/2568/1991. Off $J$ Eur Communities 248: 1-82.

EEC. 2003. Characteristics of olive and olive pomace oils and their analytical methods. EEC Regulation 1989/2003. Off $J$ Eur Communities L 295: 57-77.

El Yamani M, Sakar EH, Mansouri F, Serghini-Caid H, Elamrani A, Rharrabti Y. 2019. Effect of pigments and total phenols on oxidative stability of monovarietal virgin olive oil produced in Morocco. Riv Ital Sostanze Gr 96: 17-24.

Fernandes-Silva AA, Gouveia JB, Vasconcelos P, Ferreira TC, Villalobos FJ. 2013. Effect of different irrigation regimes on the quality attributes of monovarietal virgin olive oil from cv. "Cobrançosa". Grasas Aceites 64: 41-49.
Fitó M, de la Torre R, Covas MI. 2007. Olive oil and oxidative stress. Mol Nutr Food Res 51: 1215-1224.

Folin O, Ciocalteu V. 1927. On tyrosine and tryptophane determinations in proteins. $J$ Biol Chem 73: 627-650.

García JM, Cuevas MV, Fernández JE. 2013. Production and oil quality in "Arbequina" olive (Olea europaea, L.) trees under two deficit irrigation strategies. Irrig Sci 31: 359-370.

García JM, Morales-Sillero A, Pérez-Rubio AG, Diaz-Espejo A, Montero A, Fernández JE. 2017. Virgin olive oil quality of hedgerow "Arbequina" olive trees under deficit irrigation. $J$ Sci Food Agric 97: 1018-1026.

Gómez del Campo M, García JM. 2013. Summer deficit-irrigation strategies in a hedgerow olive cv. Arbequina orchard: effect on oil quality. J Agric Food Chem 61: 8899-8905.

Gómez-Rico A, Salvador MD, Moriana A, et al. 2007. Influence of different irrigation strategies in a traditional Cornicabra cv. olive orchard on virgin olive oil composition and quality. Food Chem 100: 568-578.

Gómez-Rico A, Salvador MD, Fregapane G. 2009. Virgin olive oil and olive fruit minor constituents as affected by irrigation management based on SWP and TDF as compared to ETc in medium-density young olive orchards (Olea europaea L. cv. Cornicabra and Morisca). Food Res Int 42: 1067-1076.

Gouvinhas I, de Almeida JM, Carvalho T, Machado N, Barros AI. 2015. Discrimination and characterisation of extra virgin olive oils from three cultivars in different maturation stages using Fourier transform infrared spectroscopy in tandem with chemometrics. Food Chem 174: 226-232.

Grattan SR, Berenguer MJ, Connell JH, Polito VS, Vossen PM. 2006. Olive oil production as influenced by different quantities of applied water. Agric Water Manag 85: 133-140.

Gucci R, Lodolini EM, Rapoport HF. 2007. Productivity of olive trees with different water status and crop load. J Hortic Sci Biotechnol 82: 648-656.

Gucci R, Caruso G, Gennai C, Esposto S, Urbani S, Servili M. 2019. Fruit growth, yield and oil quality changes induced by deficit irrigation at different stages of olive fruit development. Agric Water Manag 212: 88-98.

Gutiérrez F, Jimenez B, Ruiz A, Albi MA. 1999. Effect of olive ripeness on the oxidative stability of virgin olive oil extracted from the varieties Picual and Hojiblanca and on the different components involved. J Agric Food Chem 47: 121-127.

Gutiérrez F, Varona I, Albi MA. 2000. Relation of acidity and sensory quality with sterol content of olive oil from stored fruit. J Agric Food Chem 48: 1106-1110.

Inglese P, Barone E, Gullo G. 1996. The effect of complementary irrigation on fruit growth, ripening pattern and oil characteristics of olive (Olea europaea L.) cv. Carolea. J Hortic Sci 71: 257-263.

Iniesta F, Testi L, Orgaz F, Villalobos FJ. 2009. The effects of regulated and continuous deficit irrigation on the water use, growth and yield of olive trees. Eur J Agron 30: 258-265.

IOC (International Olive Council). 2016. Market newsletter of international olive oil council. http://www.internationaloliveoil.org.

Ismail AS, Stavroulakis G, Metzidakis J. 1997. Effect of irrigation on the quality characteristics of organic olive oil. In: III International Symposium on Olive Growing 474: 687-690.

Jiménez B, Sánchez-Ortiz A, Lorenzo ML, Rivas A. 2013. Influence of fruit ripening on agronomic parameters, quality indices, sensory attributes and phenolic compounds of Picudo olive oils. Food Res Int 54: 1860-1867.

López-Miranda J, Pérez-Jiménez F, Ros E, et al. 2010. Olive oil and health: summary of the II international conference on olive oil and 
health consensus report, Jaén and Córdoba (Spain). Nutr Metab Cardiovasc Dis 20: 284-294.

MAPMDREF (Ministère de l'Agriculture, de la Pêhe Maritime, du Développement Rural et des Eaux et Forêts-Morocco). 2019. http://www.agriculture.gov.ma/.

Marra FP, Marino G, Marchese A, Caruso T. 2016. Effects of different irrigation regimes on a super-high-density olive grove cv."Arbequina": vegetative growth, productivity and polyphenol content of the oil. Irrig Sci 34: 313-325.

Martinéz-Suárez JM. 1973. Recientes estudios de la almazara experimental del instituto de la grasa. Riv Ital Sostanze Gr 50: 325-330.

Mena C, González AZ, Olivero-David R, Pérez-Jiménez MÁ. 2018. Characterization of "Castellana" virgin olive oils with regard to olive ripening. Hort Technol 28: 48-57.

Mili S. 2006. Olive oil marketing on Non-traditional markets: prospects and strategies. New Medit 5: 27-37.

Minguez-Mosquera MI, Rejano-Navarro L, Gandul-Rojas B, SanchezGomez AH, Garrido-Fernandez J. 1991. Color-pigment correlation in virgin olive oil. J Am Oil Chem Soc 68: 332-336.

Morales-Sillero A, Fernández JE, Torres-Ruiz JM, Montero A. 2011. Influence of irrigation scheduling on fruit quality of young potted "manzanilla de sevilla" olive trees. Acta Hortic 888: 177-182.

Morelló JR, Motilva MJ, Tovar MJ, Romero MP. 2004. Changes in commercial virgin olive oil (cv Arbequina) during storage, with special emphasis on the phenolic fraction. Food Chem 85: 357-364.

Morelló JR, Romero MP, Ramo T, Motilva MJ. 2005. Evaluation of L-phenylalanine ammonia-lyase activity and phenolic profile in olive drupe (Olea europaea L.) from fruit setting period to harvesting time. Plant Sci 168: 65-72.

Motilva MJ, Romero MP, Alegre S, Girona J. 1997. Effect of regulated deficit irrigation in olive oil production and quality. In : III International Symposium on Olive Growing 474: 377-380.

Motilva MJ, Tovar MJ, Romero MP, Alegre S, Girona J. 2000. Influence of regulated deficit irrigation strategies applied to olive trees (Arbequina cultivar) on oil yield and oil composition during the fruit ripening period. $J$ Sci Food Agric 80: 2037-2043.

Nsir H, Taamalli A, Valli E, Bendini A, Gallina Toschi T, Zarrouk M. 2017. Chemical composition and sensory quality of Tunisian "Sayali" virgin olive oils as affected by fruit ripening: Toward an appropriate harvesting time. J Am Oil Chem Soc 94: 913-922.

Ouni Y, Guido F, Issaoui M, et al. 2011. Volatile compounds and compositional quality of virgin olive oil from Oueslati variety: Influence of geographical origin. Food Chem 124: 1770-1776.

Patumi M, d'Andria R, Fontanazza G, Morelli G, Giorio P, Sorrentino G. 1999. Yield and oil quality of intensively trained trees of three cultivars of olive (Olea europaea L.) under different irrigation regimes. J Hortic Sci Biotechnol 74: 729-737.

Piscopo A, Zappia A, De Bruno A, Poiana M. 2018. Effect of the harvesting time on the quality of olive oils produced in Calabria. Eur J Lipid Sci Technol 120: 1700304.

Ramos AF, Santos FL. 2010. Yield and olive oil characteristics of a low-density orchard (cv. Cordovil) subjected to different irrigation regimes. Agric Water Manag 97: 363-373.

Roca M, Minguez-Mosquera MI. 2001. Change in the natural ratio between chlorophylls and carotenoids in olive fruit during processing for virgin olive oil. J Am Oil Chem Soc 78: 133-138.

Romero MP, Tovar MJ, Girona J, Motilva MJ. 2002. Changes in the HPLC phenolic profile of virgin olive oil from young trees (Olea europaea L. Cv. Arbequina) grown under different deficit irrigation strategies. J Agric Food Chem 50: 5349-5354.
Romero C, Brenes M, Yousfi K, García P, García A, Garrido A. 2004. Effect of cultivar and processing method on the contents of polyphenols in table olives. J Agric Food Chem 52: 479-484.

Rotondi A, Bendini A, Cerretani L, Mari M, Lercker G, Toschi TG. 2004. Effect of olive ripening degree on the oxidative stability and organoleptic properties of cv. Nostrana di Brisighella extra virgin olive oil. J Agric Food Chem 52: 3649-3654.

Rufat J, Romero-Aroca AJ, Arbonés A, Villar JM, Hermoso JF, Pascual M. 2018. Mechanical harvesting and irrigation strategy responses on "arbequina" olive oil quality. Hort Technol 28: 607-614.

Salas J, Pastor M, Castro J, Vega V. 1997. Influencia del riego sobre la composición y características organolépticas del aceite de oliva. Grasas Aceites 48: 74-82.

Salvador MD, Aranda F, Fregapane G. 2001. Influence of fruit ripening on "Cornicabra" virgin olive oil quality a study of four successive crop seasons. Food Chem 73: 45-53.

Sanchez J. 1994. Lipid photosynthesis in olive fruit. Prog Lipid Res 33: 97-104.

Sastre B, Benito A, Perez MA, Cuevas A, de Lorenzo C. 2016. Effects of different irrigation regimes on plant water status, yield and oil quality of two olive cultivars. In: VIII International Olive Symposium 1199: 369-374.

Serman FV, Pacheco D, Pringles AO, Bueno L, Carelli A, Capraro F. 2011. Effect of regulated deficit irrigation strategies on productivity, quality and water use efficiency in a high-density "Arbequina" olive orchard located in an arid region of Argentina. Acta Hort 888: 81-88.

Serra-Majem L, de la Cruz JN, Ribas L, Tur JA. 2003. Olive oil and the Mediterranean diet: beyond the rhetoric. EurJ Clin Nutr 57: S2-S7.

Servili M, Esposto S, Lodolini E, et al. 2007. Irrigation effects on quality, phenolic composition, and selected volatiles of virgin olive oils cv. Leccino. J Agric Food Chem 55: 6609-6618.

Sifi S, Hamida JB, Amamou T. 2001. Impacto del sistema de trituración de las aceitunas en la calidad del aceite obtenido. Olivae 87: 33-38.

Szydłowska-Czerniak A, Trokowski K, Karlovits G, Szłyk E. 2011. Effect of refining processes on antioxidant capacity, total contents of phenolics and carotenoids in palm oils. Food Chem 129: 1187-1192.

Sönmez A, Özdikicierler O, Gümüskesen AS. 2018. Evaluation of olive oil quality during the ripening of the organic cultivated olives and multivariate discrimination of the variety with a chemometric approach. Riv Ital Sostanze Gr 95: 173-181.

Tognetti R, d'Andria R, Lavini A, Morelli G. 2006. The effect of deficit irrigation on crop yield and vegetative development of Olea europaea L. (cvs. Frantoio and Leccino). Eur J Agron 25: 356-364.

Tognetti R, d'Andria R, Sacchi R, Lavini A, Morelli G, Alvino A. 2007. Deficit irrigation affects seasonal changes in leaf physiology and oil quality of Olea europaea (cultivars Frantoio and Leccino). Ann Appl Biol 150: 169-186.

Torres MM, Maestri DM. 2006. The effects of genotype and extraction methods on chemical composition of virgin olive oils from Traslasierra Valley (Córdoba, Argentina). Food Chem 96: 507-511.

Tovar MJ, Motilva MJ, Romero MP. 2001. Changes in the phenolic composition of virgin olive oil from young trees (Olea europaea L. cv. Arbequina) grown under linear irrigation strategies. J Agric Food Chem 49: 5502-5508. 
Tovar MJ, Romero MP, Alegre S, Girona J, Motilva MJ. 2002. Composition and organoleptic characteristics of oil from Arbequina olive (Olea europaea $\mathrm{L})$ trees under deficit irrigation. J Sci Food Agric 82: 1755-1763.

Uceda M, Hermoso M, Aguilera MP. La calidad del aceite de oliva. In: Barranco D, Fernandez-Escobar R, Ediciones Mundi-Prensa LR, eds. Madrid: El Cultivo del Olivo, 1998, pp. 547-572.

Vázquez-Roncero A, Maestro-Duran R, Graciani-Constante E. 1971. Cambios en los polifenoles de la aceituna durante la maduración. Grasas Aceites 22: 366-370.

Velasco J, Dobarganes C. 2002. Oxidative stability of virgin olive oil. Eur J Lipid Sci Technol 104: 661-676.

Yorulmaz A, Erinc H, Tekin A. 2013. Changes in olive and olive oil characteristics during maturation. J Am Oil Chem Soc 90: 647-658.
Yousfi K, Cert RM, García JM. 2006. Changes in quality and phenolic compounds of virgin olive oils during objectively described fruit maturation. Eur Food Res Technol 223: 117-124.

Zamora R, Alaiz M, Hidalgo FJ. 2001. Influence of cultivar and fruit ripening on olive (Olea europaea) fruit protein content, composition, and antioxidant activity. J Agric Food Chem 49: 4267-4270.

Zeleke KT, Ayton J. 2014. Fruit and oil quality of olive (Olea europaea L.) under different irrigation regimes and harvest times in south eastern Australia. J Food Agric Environ 12: 458-464.

Zeleke K, Mailer R, Eberbach P, Wünsche J. 2012. Oil content and fruit quality of nine olive (Olea europaea L.) varieties affected by irrigation and harvest times. New Zeal J Crop Hort 40: 241-252.

Zunin P, Evangelisti F, Pagano MA, Tiscornia E, Petacchi R. 1995. Phenolic compounds in oil obtained from Olea europaea and antiDacus treatments. Riv Ital Sostanze Gr 72: 55-59.

Cite this article as: El Yamani M, Sakar EH, Boussakouran A, Rharrabti Y. 2020. Influence of ripening index and water regime on the yield and quality of "Moroccan Picholine" virgin olive oil. OCL 27: 19. 